\title{
A Revolution Whose Time Has Come? The Win-Win of Quantitative Participatory Approaches and Methods
}

\author{
Robert Chambers
}

\begin{abstract}
This article explores the potential presented by quantitative participatory methods (QPMs) and approaches for agricultural monitoring and evaluation and impact assessment. Pioneering examples indicate that QPMs can be 'win-win', with gains to farmers through their own analysis, action and voice, and to scientists and other non-farming professionals through the accuracy, relevance, scope and timeliness of the information and insights they generate. To realise their potential requires professional, academic, institutional and personal commitment and change.
\end{abstract}

\begin{abstract}
1 Introduction
The Agricultural Learning and Impacts Network (ALINe) seeks to pilot approaches to farmer feedback that put farmers' views at the centre of measurement and create real incentives to responsiveness. Much of the problem is said to be weak monitoring and evaluation and impact assessment (M\&E and IA) in agriculture. This article sets out to give sources and review experience with quantitative participatory methods (QPMs) (aka participatory numbers or participatory statistics) and to assess their relevance and potential. It concludes by pointing to ways forward.
\end{abstract}

The basic issue is orientation. If $\mathrm{M} \& \mathrm{E}$ and IA are weak, for whom are they weak? ${ }^{1}$ Are they weak for 'us', professionals concerned with agricultural development, or weak for 'them', the farmers and pastoralists, many of them marginal and resourcepoor, whose interests are meant to be served? Whose M\&E and IA is it? Undertaken for whom? With what costs to whom? And for whose benefit? Some M\&E and IA has been extractive through methods of investigation like questionnaires which can take farmers' time without direct benefits for them. In other cases they have relied on expensive monitoring and measurement. The question is whether QPMs can present win-win participatory solutions in which M\&E and IA can

bring gains to both farmers and outsiders.

\section{What have we learnt?}

Much has been learnt about QPMs that is relevant to answering that question, but much of it is inadequately recognised by professional establishments. We have learnt that:

1 'They can do it'. Farmers and pastoralists have far greater capabilities than most professionals have supposed. This has become increasingly evident and recognised during the past three decades. Not least this has been through the Farmer Participatory Research (FPR) of the late 1980s and early 90s (see for example Biggs 1988; Farrington and Martin 1988; Sumberg and Okali 1989; Ashby 1990), farmer field schools and integrated pest management (Dilts 2001; Pontius et al. 2002), and most notably participatory seed breeding (Maurya $e t$ al. 1988; Witcombe et al. 1996; Stirling and Witcombe 2004; Witcombe et al. 2005). These have repeatedly shown farmers to have capabilities far beyond those earlier supposed by agricultural and other professionals, as with the extraordinary spread and power of Participatory Geographic Information Systems (PLA 2006; Mbile 2006).

IDS Bulletin Volume 41 Number 6 November 2010 C 2010 The Author. Journal compilation (c) Institute of Development Studies Published by Blackwell Publishing Ltd, 9600 Garsington Road, Oxford OX4 2DQ, UK and 350 Main Street, Malden, MA 02148, USA 


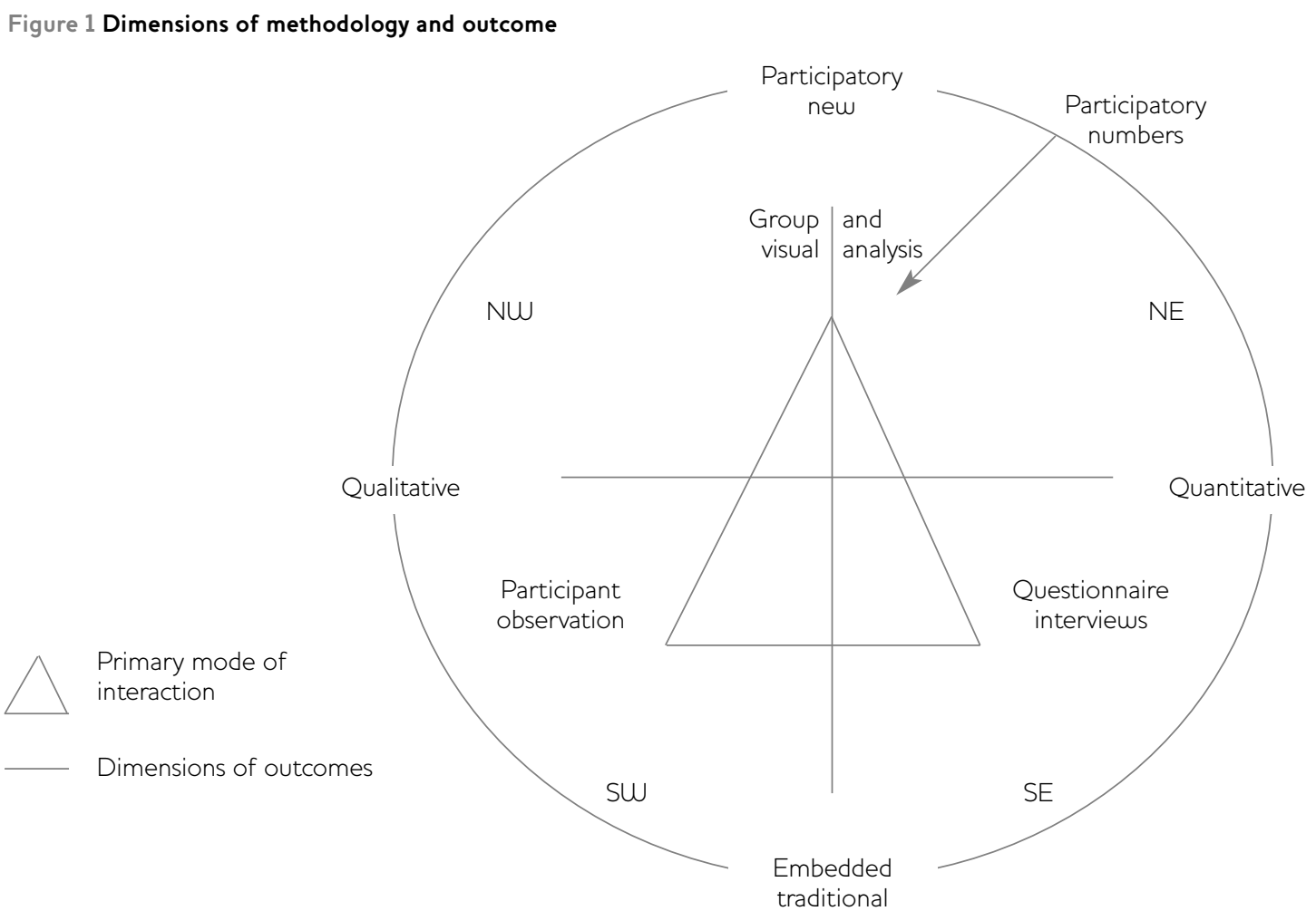

Source Chambers (2008).

2 Farmers and pastoralists can quantify. We now know that when facilitated in a participatory mode in groups and with methods that are visual and tangible, farmers, pastoralists and others, whether literate or not, can count, measure, estimate, rank, score, value, and compare, and so generate numbers. The NE quadrant in Figure 1 has been largely overlooked because of the embedded training and practices of questionnaires, reinforced by the enduring and erroneous stereotype of 'participatory' as only qualitative as if confined to the NW quadrant. In much farmer participatory research farmers weigh, measure, estimate and value. By the mid 1990s there were already many examples where participatory methods had produced numbers and statistics through methods that variously used or combined listing, card sorting, ordinal ranking (Bayer 1988), pairwise ranking, matrix scoring (Drinkwater 1993; Freudenberger 1995; Manoharan et al. 1993), pile sorting (proportional piling) (Watson 1994; Eldridge 2001; Catley et al. 2008) and aggregating from focus groups (Swift and Umar 1991; ActionAid 1992). These methods were also used with individual farmers as in a Save the Children Fund study of farmers' adaptations to drought in
Malawi, Zambia and Zimbabwe (Eldridge 1995, 1998). Such methods were used in field activities of the Participatory Research and Gender Analysis network of the Consultative Group for International Agricultural Research (CGIAR) (PRGA 2002). More recently these methods have been evolved and combined in many ways. Innovations include cardinal ranking positioning cards on a rope scale (Kagugube et al. 2007). Across disciplines and sectors there are now many descriptions, guides, source books and analyses (see e.g. Shah et al. 1999; World Bank 1999; Jayakaran 2002, 2007; Mukherjee 2002, 2009; Mayoux 2005; International HIV/AIDS Alliance 2006) and several analyses (see for example Barahona and Levy 2003, 2007; Mayoux and Chambers 2005; Chambers 2008).

3 Participatory numbers can be analysed like other statistics. The classic works on this are by statisticians at the Centre for Statistical Services, Reading University, who have facilitated participatory numbers from various methods, and have devised ad hoc sequences for specific purposes (Burn 2000; Barahona and Levy 2003, 2007; Barahona 2005; Levy 2003, 2005, 2007). 
4 QPMs can quantify the qualitative. QPMs can quantify almost any qualitative dimension open to human judgement, for example aspects of wellbeing (White and Pettit 2004). In a large-scale programme in a social movement in Bangladesh, aggregation from annual focus groups can quantify dimensions of social change (Jupp and Ali 2010). Common examples in agriculture are matrix scoring of comparisons of the many qualities farmers express as significant in varieties of the same crop, as with finger millet in Zambia (Drinkwater 1993) (taste in beer, meal quality, resistance to bird damage, etc.) and bananas in Tamil Nadu (Manoharan et al. 1993) (marketability, disease resistance, etc.). For their part pastoralists have used matrix scoring for comparing service providers (see Table 1) (Catley et al. 2008: 53).

5 QPM numbers are often better ${ }^{2}$ than those generated in other ways. The word alternative as in alternative statistics (Archer and Newman 2003) applied to such numbers should not give the impression that they are soft or second best. On the contrary they are usually more accurate and relevant than those from questionnaires and censuses, sometimes spectacularly so. Ad hoc inventive design can lead to tables with a credible rigour and accuracy inaccessible by other means (see e.g. Levy 2003 and 2005 for finding out who benefited from the Malawi Starter Pack programme). The rigour of trustworthiness and relevance manifests through design, critical participatory facilitation, and observation of group-visual synergy - participants committed to 'getting it right' and triangulation with visual crosschecking and progressive interactive approximation (Chambers 1997: 154-61). Evidence of the accuracy and power of participatory numbers has been accumulating over the past two decades (see Gill 1991 for a remarkable early example). Summaries, overviews and critical analyses (e.g. Abeyasekera 2001; Burn 2000; Barahona and Levy 2003, 2007; Chambers 2008 chapter 6; Mayoux and Chambers 2005) present evidence from many domains. A remarkable case was the credible identification of a census undercount of the order of 36 per cent found in the rural population of Malawi through participatory census mapping triangulated with a one-page questionnaire (Barahona and Levy 2003).
6 To evolve fitting participatory methodologies requires participatory attitudes and behaviour and takes time. Participatory methods, like mapping or matrix scoring, require appropriate behaviour and attitudes, but are versatile and fairly straightforward; they do not require extensive trials. In contrast, to evolve a methodology that combines methods and approaches to fit a context and purpose can take time, skill, inventiveness, patience and progressive piloting. To develop the methodology used in Malawi for impact assessment of the 'starter pack' with farmers' indicators of sustainability (of which there came to be 15) (Cromwell et al. 2001) took a team three weeks of continuous and intensive participatory fieldwork and trials (pers. comm. Fiona Chambers). The impact assessment methods and processes used with pastoralists in East Africa to generate relevant statistics and insights were developed over a matter of years (Catley 2009; Catley et al. 2008).

7 Farmers will only participate well if they see benefits. In the days of farming systems research in the 1970s and early 1980s, many attempts to induce farmers to keep numerical records of their farming activities appeared successful for a short time, but this reflected politeness and prudence more than perceived gains, and rarely if ever lasted. For sustained participation, farmers must feel that in some way or some combination of ways such as in farming practices and benefits, or socially or through learning and enjoyment, they are getting something out of it.

8 Many factors have stood in the way of recognising the above. The references to published sources from the 1990s and earlier given above make the point that many of the QPM breakthroughs have been with us for decades. However, they have not entered the mainstream. The obstacles to recognising participatory numbers, farmers' abilities, and their incentives, have been professional, institutional and personal. Traditional mindsets and methods are reproduced by educational and training systems; paradoxically, academics and trainers can be the last to learn and change. To this there are outstanding exceptions as we will see. But the glass is largely empty, so the space left and the potential are big. 


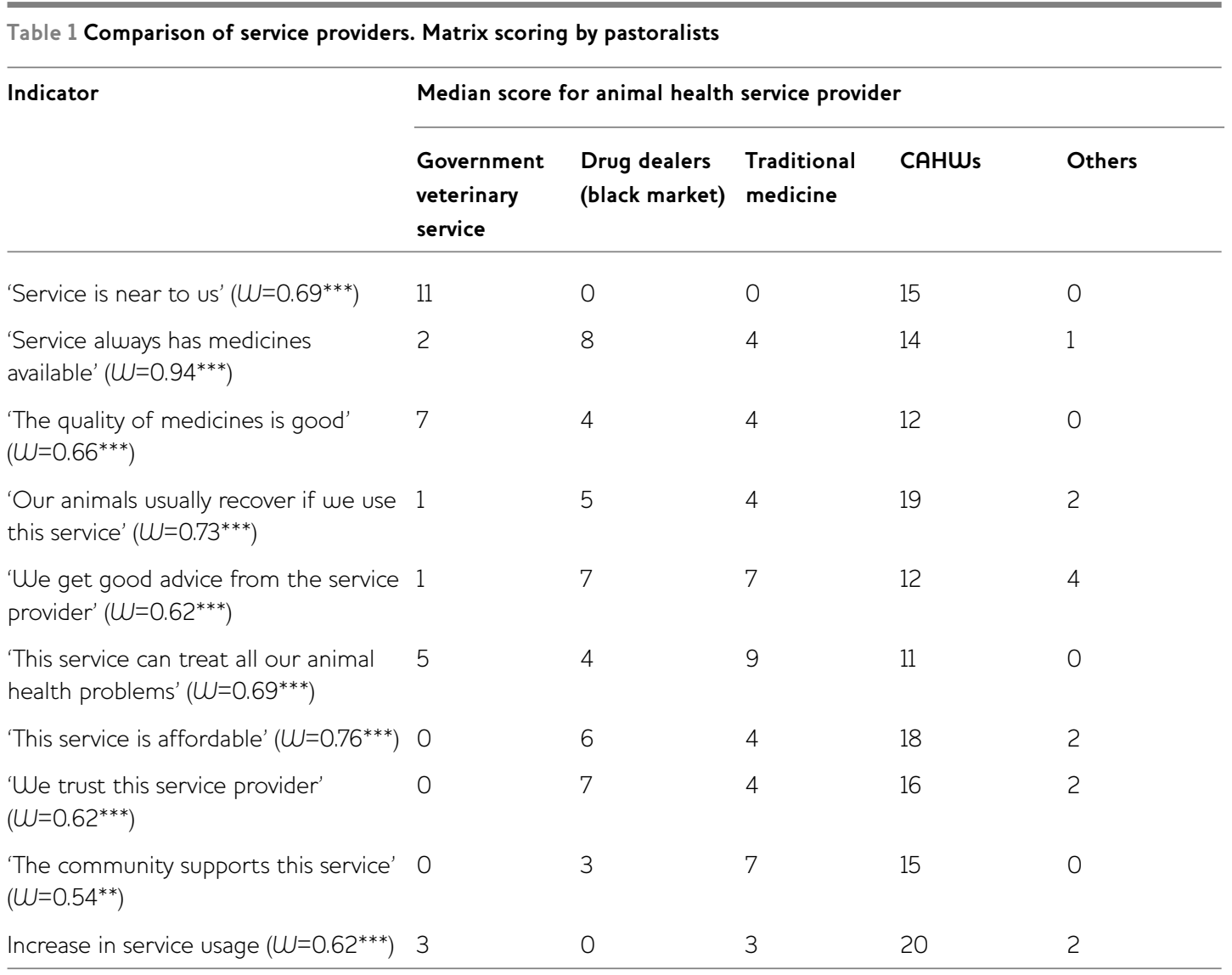

CAHWs: Community Animal Health Workers

Source Admassu et al. (2005) reproduced in Catley et al. (2008: 53), https://wikis.uit.tufts.edu/confluence/display/FIC/ Participatory+Impact+Assessment (accessed 3 September 2010). Reproduced with kind permission by Andrew Catley.

\section{Applications in participatory M\&E and IA} Much early participatory $\mathrm{M} \& \mathrm{E}$ and IA was mainly qualitative (see e.g. Estrella and Gaventa 1997; Estrella et al. 2000). Guijt (1998) is an early example of participatory $\mathrm{M} \& \mathrm{E}$ generating numbers - with pocket charts, ranking, and some other participatory quantification. Since then innovations in the 2000s have increasingly introduced quantitative elements. Instances have proliferated in fields other than agriculture. To take one example, in Bangladesh as recorded in Measuring Empowerment? Ask Them (Jupp and Ali 2010), a social movement with some half a million members has shown that focus groups facilitated by themselves can produce statistics for their annual assessments of social change, with 132 of their own indicators identified through a participatory process.

In agriculture, two developments illustrate innovation and show what can be done.
First, participatory epidemiology (PE) in East Africa (Catley 2009; Abebe et al. 2009) has a history which goes back to participatory rural appraisal (PRA) in the early 1990s (RRA Notes 1994; Conroy 2005). Participatory impact assessment (PIA) (Catley et al. 2008) draws heavily on PE. PRA methods, especially matrix scoring and proportional piling, have been facilitated with pastoralists to generate statistics. Typically these use small stones separated into proportional piles or allocated to the cells of matrices drawn on earth or sand. The approach and methods of PE are included as a section in Thrusfield's (2005) well-known ${ }^{3}$ textbook Veterinary Epidemiology. Retrospective baselines are established through before-and-after proportional piling (Abebe et al. 2009: 297); and where numbers are sensitive, as with numbers of livestock, or difficult to assess as with other dimensions of wealth, comparisons are made with a nominal baseline represented physically by counters or 


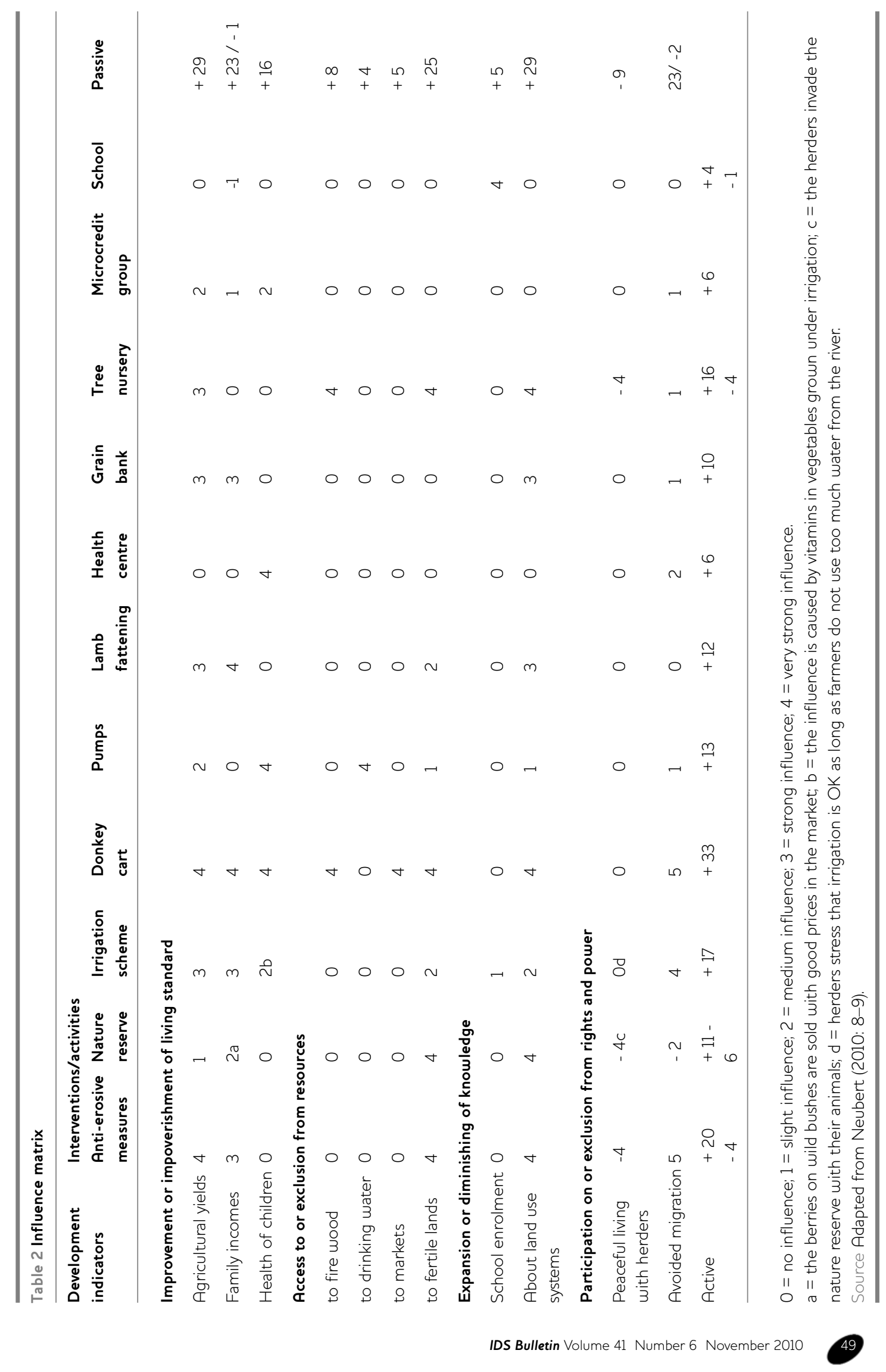




\section{Box 1 Farmers' empowerment through participatory numbers: an afternoon in Eritrea}

Six of us visited a village. We had all been trained in PRA behaviours and knew to keep quiet. One of us was from the Land Commission. The Government was proposing land consolidation, to bring scattered fields together. We met the village leader in his hut. After a discussion we asked him what would be a good land policy for his village. He replied:

Whatever the Government says is right.

Outside, a woman farmer invited us for tea. The village head and another farmer came with us. We had a long informal discussion about crops. All of us remained silent except for the facilitator/interviewer. He asked if they could draw a map of the village land, showing agroecological zones. With chalk and enthusiasm they drew a large map on the mud floor. This showed six zones. Then they were asked to count out 100 maize grains and draw a matrix of agroecological zones down the side and their main crops across the top. With much debate, and changes in the scores, they placed the seeds in the matrix, scoring for 'importance', a composite score for the crop and zone, showing the complexity of their farming system and how farmers needed land in several zones.

\begin{tabular}{|c|c|c|c|c|c|c|c|c|}
\hline & Maize & Barley & Teff & Wheat & Sorghum & $\begin{array}{l}\text { Finger } \\
\text { millet }\end{array}$ & $\begin{array}{l}\text { Beans and } \\
\text { peas }\end{array}$ & Total \\
\hline Gedena & 3 & 3 & 5 & & & & & 11 \\
\hline Member & & 15 & 8 & 6 & & & 6 & 35 \\
\hline Zagiena & & 4 & & 4 & & & 4 & 12 \\
\hline Tsebaria & & & & & 9 & 5 & & 14 \\
\hline Waleha & & & 7 & & 6 & & 6 & 19 \\
\hline Huza & & & & & & 4 & 5 & 9 \\
\hline Total & 3 & 22 & 20 & 10 & 15 & 9 & 21 & 100 \\
\hline
\end{tabular}

Method: Listing after mapping then scoring with 100 maize grains on the matrix drawn with chalk. Analysts: Habtemariqa Weldai, Gebru Zerehun, Aberash T/Maimanot.

When they had finished, and the spread of scores across the crops and zones could be seen by everyone, the same head of the village turned to the official from the Land Commission and said:

Now you can see why your policy will not work.

The map and matrix were later debated in policy circles in Asmara.

stones. Causality and attribution are analysed in similar visual numerical ways with applications such as the matrix scoring of the impact of community animal health workers in Ethiopia (Table 1). Conventional statistical methods have been applied to these data - SPSS Version 11.0, calculations of medians and ranges, the Kendall coefficient of concordance, and the Wilcoxon Signed Ranks test (Abebe et al. 2009: 297).
Second, MAPP (Method for Impact Assessment of Programmes and Projects) is a methodology through which 'farmers are evaluating the impacts of development interventions following a logical structure' (Neubert 2010). ${ }^{4}$ MAPP has been used by the Swiss Agency for Development and Cooperation (SDC) and GTZ. It builds on PRA tools to enable communities to describe changes they have experienced, rate the 
relevance of different development interventions and systematically attribute causes to effects. It was developed by Susanne Neubert [of the German Development Institute] in the late 1990s and has been used by NGOs for selfassessment, in external impact studies and in cross-cutting sectoral impact studies (Bernard Causemann pers. comm.). The tools include a life curve showing overall development trends experienced, trend analysis, cross-checking through transect walks, listing interventions and activities, and an influence matrix, as in Table 2 in which people give positive and negative scores interventions against impacts. Controls are through convening separate groups of benefiting and non-benefiting farmers. The importance of convening groups representing different clusters of interest, such as women and men, farmers and pastoralists, is recognised. MAPP also contributes a straightforward method for distinguishing positive and negative effects.

It would be difficult to overstate the significance of PE and MAPP, or the importance of learning from them and from other similar participatory innovations. Both PE and MAPP involve facilitated group discussions with the use of PRA (participatory rural appraisal) visualisations especially matrix scoring (Drinkwater 1993; Manoharan et al. 1993; Jones 1996a, b; Chambers 1997) and collective assessments and judgements, as in Tables 1 and 2. Both use indicators, categories and criteria generated by farmers or pastoralists from their own experience and values. Through their combinations of methods, they present logical, rigorous and credible ways for dealing with some of the persistent problems of evaluation, namely attribution, controls, and unanticipated and otherwise unidentified consequences.

\section{Win-wins and ways forward}

The evidence is now stronger than ever that participatory approaches and methods can generate good numbers and statistics; that through participatory comparisons almost any dimension that is qualitative can be quantified; and that farmers and pastoralists can gain from participatory analyses that generate numbers, both for their own understanding and action, and through amplifying their voices. The processes of generating participatory numbers can themselves empower, enabling farmers to analyse and present to policymakers the complexity and diversity of their farming systems, as shown in a participatory afternoon with farmers in Eritrea (Box 1).

Such numbers can be powerful and persuasive. As Archer and Newman put it (2003: evaluation no. 16) in a wider context 'Statistics are a very powerful campaigning tool - and can be used to support the demands a group are trying to achieve by demonstrating a particular point of view, or the reality on the ground'. Statistics from report cards (Paul 2002; Kumar and Shah 2004; Jacobs, this IDS Bulletin) on the performance of agricultural extension are an obvious and direct application. QPMs have been, or could be, applied in any domain of farmer, fisher, pastoralist or natural resource user interest or activity: resource depletion, degradation or enhancement, yields, non-timber forest products, fishing stocks, market prices, value chains, extension services, and so on. The grounding of QPMs in people's lived experience and reality can empower them and at the same time inform projects, programmes and policymakers. In short, QPMs can be win-wins from which most or all stakeholders can gain.

The survey of agricultural M\&E (Lindstrom 2009) revealed a paradox: accountability to 'beneficiaries' and their empowerment were considered the two weakest functions of current agricultural M\&E; yet developing new M\&E models and tools was rated the lowest but one in importance of eight different approaches to improving M\&E in agriculture. QPMs can be used to develop new forms of participatory $M \& E$ to tackle the two weaknesses by empowering primary stakeholders (farmers, pastoralists, etc.) both through their learning and their use of statistics in lobbying and holding others to account. Why then are QPMs and approaches still so little recognised and so rare? Among other explanations, two stand out.

The first is the sense that 'we know how to do it'. This is manifest in the current promotion of randomised controlled trials as a gold standard for rigour and cost-effectiveness and in the persistent preference for questionnaires as a means of obtaining numerical data. Part of the longer term way forward here is to test the relative cost-effectiveness of RCTs and questionnaires ${ }^{6}$ on the one hand, and participatory approaches on the other, in a suitable spread of contexts. Cost here would 
include finance, transaction costs, human resources, and farmers' and pastoralists' time, and effectiveness would be in terms of benefits through farmers' and pastoralists' learning, action and voice, and through the timeliness, relevance, scope and quality of the influence of the process and findings on professional learning and change, including capacity development, programmes, projects and policies. Likely and good outcomes from such tests would be support for methodological diversity (Van Mele et al. 2005; Van Mele and Braun 2005) and pluralism, and the ability to make better informed choices of methods.

The second explanation is inertia. Thus Andy Catley (2009: 254): 'In common with many other participatory approaches and methods, the issues facing PE are still largely institutional, not methodological'. Many universities, with notable exceptions in Ethiopia, continue to teach, train and condition students in the embedded methods of established convention, and to launch them on their careers with restricted vision and skills. Part of the long-term solution here is long-term commitment and campaigns, as was pioneered by the PE programme, for direct hands-on field learning by academics, government staff and

\section{Notes}

1 There can be at least 40 of these who? and whose? questions. They can be asked of many development activities. They point to dimensions of power, ethics and practical utility. See Rambaldi et al. (2006).

2 This assumes similar quality of facilitation and implementation in the approaches being compared. There is a wealth of evidence to support this rather modest assertion. See for example Chambers (1997: ch. 7 and 2008: ch. 6), and Barahona and Levy (2003, 2007). The rigour of triangulation, successive approximation and emergence in observed group-visual synergy (Chambers 1997: 158-61) is still almost entirely unrecognised in the mainstreams of orthodox professionalism. The issue is paradigmatic, between dominant neo-Newtonian practices and participatory and adaptive pluralism which accommodates and expresses complexity and emergence (Chambers 2010). others, so that they can add to their understanding and repertoire of approaches and methods.

The transformations we need for the potential of QPMs to be recognised and realised in practice are professional, academic and institutional. They are also personal. As with all revolutions, the key is committed champions who see what needs to happen and who makes it happen. QPMs have until recently had few champions with the conviction, continuity and clout to assure their development, introduction, use and spread. But the widespread frustration and dissatisfaction with current methods and approaches, and growing recognition of the rigour and win-win character of QPMs, provide a seedbed for change.

Given the many innovations and applications of the past two decades, only a very few of which have been described above, the time for the win-wins of participatory numbers and statistics should surely now have come. For this to happen, many more professionals need to be inspired and emboldened to dare to adopt and adapt them, to experience their win-win qualities, to become champions and innovators, and to share their learning. The many millions of small and resource-poor farmers of our world deserve no less.

3 I am not familiar with the work but am citing Andy Catley (2009).

4 Methodological issues are discussed in Susanne Neubert Methodischer Fachbericht zum ersten Wirkungsbericht der DEZA 2008 [Methodical Technical Report for the First Impact Report of DEZA 2008], DIE/GDI Bonn at www.diegdi.de/CMS-Homepage/openwebcms3.nsf (accessed 17 June 2010), pers. comm. Bernard Causemann.

5 Depending on context, losers might include some in value chains, or some who gain from extortion or corruption.

6 Comparing PRA tools and processes with questionnaires is not a new subject. There is already much evidence. A literature review and assessment would be a first step, see e.g. Mukherjee (1995) and Chambers (1997: 122-5, 141-5, 15-5). 


\section{References}

Abebe, D.; Catley, A.; Admassu, B. and Bekele, G. (2009) 'Using Participatory Impact Assessment (PIA) to Inform Policy: Lessons from Ethiopia', in I. Scoones and J. Thompson (eds), Farmer First Revisited, Rugby: Practical Action Publishing: 296-300

Abeyasekera, Savitri (2001) Analysis Approaches in Participatory Work Involving Ranks or Scores, Statistical Services Centre, University of Reading, UK

ActionAid-Nepal (1992) Participatory Rural Appraisal Utilisation Survey Report Part 1: Rural Development Area Sindhupalchowk, Kathmandu: Monitoring and Evaluation Unit, ActionAidNepal

Admassu, B.; Nega, S.; Haile,T.; Abera, B.; Hussein, A. and Catley, A. (2005) Impact Assessment: Experience of the African Wildlife Foundation in East Africa, Sustainable Livelihoods Working Paper 129, London: Overseas Development Institute

Archer, David and Newman, Kate (compilers) (2003) Communication and Power: Reflect Practical Resource Materials, London: ActionAid, www.reflectaction.org/ (accessed 14 December 2006)

Ashby, J.A. (1990) Evaluating Technology with Farmers: A Handbook, IPRA Projects, Cali, Colombia: Centro Internacional de Agricultura Tropical (CIAT)

Barahona, Carlos (2005) 'Experience and Innovation: How the Research Methods Evolved', in Levy, S. (ed.) (2005) Starter Packs: A Strategy to Fight Hunger in Developing Countries? Lessons from the Malawi Experience, 1998-2003, Wallingford: CABI: 77-92

Barahona, C. and Levy, S. (2007) 'The Best of Both Worlds: Producing National Statistics using Participatory Methods', World Development 35.2: 326-41

Barahona, C. and Levy, S. (2003) How to Generate Statistics and Influence Policy Using Participatory Methods in Research: Reflections on Work in Malawi 1999-2002, IDS Working Paper 212, Brighton: IDS

Bayer, W. (1988) 'Ranking of Browse Species by Cattlekeepers in Nigeria', RRA Notes 3, 4-10 London: International Institute for Environment and Development (IIED)

Biggs, S. (1988) Resource-poor Farmer Participation in Research: A Synthesis of Experiences from Nine National Agricultural Research Systems, The Hague: International Service for National Agricultural Research (ISNAR)
Burn, R.W. (2000) Quantifying and Combining Causal Diagrams, Statistical Guides Series, Statistical Services Centre, University of Reading, UK

Catley, A. (2009) 'From Marginal to Normative: Institutionalizing Participatory Epidemiology', in I. Scoones and J. Thompson (eds), Farmer First Revisited, Rugby: Practical Action Publishing: 247-54

Catley, A.; Burns, J.; Abebe, D. and Suji, S. (2008) Participatory Impact Assessment: A Guide for Practitioners, Medford, MA: Feinstein International Center, Tufts University, https://wikis.uit.tufts.edu/confluence/display/ FIC/Participatory+Impact + Assessment (accessed 3 September 2010)

Chambers, R. (2010) Paradigms, Poverty and Adaptive Pluralism, IDS Working Paper 344, Brighton: IDS

Chambers, R. (2008) Revolutions in Development Inquiry, London and Sterling, VA: Earthscan

Chambers, R. (1997) Whose Reality Counts? Putting the First Last, London: Intermediate Technology Publications

Conroy, Czech (2005) Participatory Livestock Research: A Guide, Bourton-on-Dunsmore, Warwickshire: ITDG Publishing

Cromwell, E.; Kambewa, P.; Mwanza, R. and Chirwa, R. with KWERA Development Centre (2001) Impact Assessment Using Participatory Approaches: 'Starter Pack' and Sustainable Agriculture in Malawi, Network Paper 112, Agricultural Research and Extension Network, London: Overseas Development Institute

Dilts, R. (2001) 'From Farmers' Field Schools to Community IPM', LEISA 17.3: 18-21

Drinkwater, Michael (1993) 'Sorting Fact from Opinion: The Use of a Direct Matrix to Evaluate Finger Millet Varieties', RRA Notes 17: 24-8

Eldridge, C. (2001) Investigating Change and Relationships in the Livelihoods of the Poor Using an Adaptation of Proportional Piling, UK Save the Children

Eldridge, C. (1998) 'Summary of the Main Findings of a PRA Study on the 1992 Drought in Zimbabwe', London: Save the Children

Eldridge, C. (1995) Methodological Notes, Instructions to Facilitators, Household Responses to Drought Study in Malawi, Zambia, and Zimbabwe, London: Save the Children

Estrella, M. and Gaventa,J. (1997) Who Counts Reality:? Participatory Monitoring and Evaluation: A 
Literature Review, Brighton: Participation Group, IDS

Estrella, Marisol with Blauert, Jutta; Campilan, Dindo; Gaventa, John; Gonsalves, Julian; Guijt, Irene; Johnson, Deb and Ricafort, Roger (2000) Learning from Change: Issues and Experiences in Participatory Monitoring and Evaluation, London: Practical Action Publishing

Farrington, John and Martin, Adrienne (1988) Farmer Participation in Agricultural Research: A Review of Concepts and Practices, Agricultural Administration Unit Occasional Paper 9, London: Overseas Development Institute

Freudenberger, Karen Schoonmaker (1995) 'The Historical Matrix - Breaking Away from Static Analysis', Forests, Trees and People Newsletter 26/27: 78-9

Gill, G. (1991) 'But How Does it Compare with the Real Data?', RRA Notes 14: 5-14 London: International Institute for Environment and Development (IIED) (also Research Report Series 16, HMG Ministry of AgricultureWinrock International, Kathmandu, January 1992)

Guijt, Irene (1998) Participatory Monitoring and Impact Assessment of Sustainable Agriculture Initiatives, SARL Discussion Paper 1, Sustainable Agriculture and Rural Livelihoods Programme, London: International Institute for Environment and Development (IIED)

International HIV/AIDS Alliance [Josh Levene] (2006) Tools Together Now: 100 Participatory Tools to Mobilise Communities for HIV/AIDS, Brighton: International HIV/AIDS Alliance

Jayakaran, Ravi (2007) New Participatory Tools for Measuring Attitude, Behaviour, Perception and Change (an overview of some of the new participatory tools being used for assessment and evaluation) Ravi_Jayakaran@online.com.kh and Ravi@Jayakaran.com

Jayakaran, R. (2002) The Ten Seed Technique, www.entrepreneursdumonde.org/pratiques/ files/Ten-Seed Technique (accessed 6 May 2010)

Jones, C. (1996a) PRA Methods, Topic Pack, Participation Group, Brighton: IDS

Jones, C. (1996b) 'Matrices, Ranking and Scoring: Participatory Appraisal "Methods" Paper', Participation Group, Brighton: IDS

Jupp, D. and Ali, S.I. (2010) Measuring Empowerment? Ask Them, Stockholm: Swedish International Development Agency, www.sida.se (accessed 17 August 2010)

Kagugube, Johnson; Ssewakiryanga, Richard; Barahona, Carlos and Levy, Sarah (submitted
2007) 'Integrating Qualitative Dimensions of Poverty into the Third Uganda National Household Survey' (UNHS III), Journal of African Statistics

Kumar, S. and Shah, P. (2004) 'Velugu: Operational Manual for Implementing the Community Scorecard Process', draft, May, Andhra Pradesh Rural Poverty Reduction Project www.sasanet.org/documents (accessed 6 May 2010)

Levy, Sarah (2007) 'Using Numerical Data from Participatory Research to Support the Millennium Development Goals: The Case for Locally Owned Information Systems', in K. Brock and J. Pettit (eds), Springs of Participation: Creating and Evolving Methods for Participatory Development, Rugby: Practical Action Publishing: 137-49

Levy, Sarah (ed.) (2005) Starter Packs: A Strategy to Fight Hunger in Developing Countries? Lessons from the Malawi Experience, 1998-2003, Wallingford: CABI Publishing

Levy, Sarah (2003) 'Are we Targeting the Poor? Lessons from Malawi', PLA Notes 47: 19-24

Lindstrom, J. (2009) What is the State of MEE in Agriculture? Findings of the ALINe Online Consultation Survey, www.aline.org.uk/pool/ what-is-the-state-of-mande-in-agriculture.pdf (accessed 16 July 2010)

Manoharan, M.; Velayudham, K. and Shunmugavalli, N. (1993) 'PRA: An Approach to find Felt Needs of Crop Varieties', $R R A$ Notes 18: 66-8

Maurya, D.M.; Bottrall, A. and Farrington, J. (1988) 'Improved Livelihoods, Genetic Diversity and Farmer Participation: A Strategy for Rice-breeding Rainfed Areas of India', Experimental Agriculture 24.3: 31 1-20

Mayoux, L. (2005) 'Quantitative, Qualitative or Participatory? Which Method, for What and When?', in Desai and Potter (eds), Doing Development Research 115-29

Mayoux, L. and Chambers, R. (2005) 'Reversing the Paradigm: Quantification, Participatory Methods and Pro-poor Impact Assessment', Journal of International Development 17: 271-98, published online in Wiley InterScience www.interscience.wiley.com (accessed 17 August 2010)

Mbile, Peter (ed.) (2006) Electronic Journal of Information Systems in Developing Countries: Special Issue on Participatory Geographical Information Systems and Participatory Mapping 25, www.ejisdc.org (accessed 17 August 2010) 
Mukherjee, N. (2009) Speaking to Power: 27 Voice Tools: Building Bridges for Participatory Learning, Action and Policy-making, New Delhi: Concept Publishing House

Mukherjee, N. (2002) Participatory Learning and Action with 100 Field Methods, New Delhi: Concept Publishing Company

Mukherjee, N. (1995) Participatory Rural Appraisal and Questionnaire Survey: Comparative Field Experience and Methodological Innovations, New Delhi: Concept Publishing Company

Neubert, Susanne (2010) Description and Examples of MAPP: Method for Impact Assessment of Programmes and Projects, Bonn: German Development Institute

Paul, B. (2002) Holding the State to Account: Gitizen Monitoring in Action, Bangalore: Books for Change

PLA (2006) 'Mapping for Change: Practice, Technologies and Communications', Participatory Learning and Action 54

Pontius, John; Dilts, Russell and Bartlett, Andrew (eds) (2002) From Farmer Field School to Community IPM: Ten Years of IPM Training in Asia, Bangkok: FAO Regional Office for Asia and the Pacific

PRGA (c.2002) PRGA Program: Synthesis of Phase I (1997-2002), Program on Participatory Research and Gender Analysis, Consultative Group for International Agricultural Research (CGIAR)

Rambaldi, G.; Chambers, R.; McCall, M. and Fox, J. (2006) 'Practical Ethics for PGIS Practitioners, Facilitators, Technology Intermediaries and Researchers', Participatory Learning and Action 54: 106-13

RRA Notes [now Participatory Learning and Action] (1994) 'Special Issue on Livestock', London: International Institute for Environment and Development (IIED)

Scoones, I. and Thompson, J. (eds) (2009) Farmer First Revisited: Innovation for Agricultural Research and Development, Rugby: Practical Action Publishing

Shah, Meera Kaul with Zambezi, Rose and Simasuku, Mary (1999) Listening to Young Voices: Facilitating Participatory Appraisals on Reproductive Health with Adolescents, Zambia: CARE International

Stirling, G.M. and Witcombe, J.R. (eds) (2004) Farmers and Plant Breeders in Partnership, 2nd edn, Bangor, UK: Centre for Arid Zone Studies Sumberg, J. and Okali, C. (1989) 'Farmers, On- farm Research, and New Technology', in R. Chambers, A. Pacey and L.A. Thrupp (eds), Farmer First, London: Practical Action Publishing: 109-14

Swift, Jeremy and Umar, Abdi Noor (1991) Participatory Pastoral Development in Isiolo District: Socio-economic Research in the Isiolo Livestock Development Project, Isiolo, Kenya: EMI ASAL Programme

Thrusfield, M. (2005) Veterinary Epidemiology, 3rd edn, Oxford: Blackwell Science (cited in Catley 2009)

Van Mele, Paul and Braun, Ann, R. (2005) 'Importance of Methodological Diversity in Research and Development Innovation Systems', in Gonsalves et al. (eds), Participatory Research and Development for Sustainable Agriculture and Natural Resource Management: A Sourcebook. Volume 1: Understanding Participatory Research and Development, Laguna, Philippines: International Potato Center-Users' Perspectives With Agricultural Research and Development, and Ottawa, Canada: IDRC: 151-6

Van Mele, Paul; Salahuddin, Ahmad and Magor, Noel P. (eds) (2005) Innovations in Rural Extension: Case Studies from Bangladesh, Wallingford, UK and Cambridge, MA: CABI Publishing

Watson, K. (1994) 'Proportional Piling in Turkana: A Case Study', RRA Notes 20: 131-2

White, S. and Pettit, J. (2004) Participatory Approaches and the Measurement of Human Wellbeing, WeD Working Paper 08, UNU-WIDER

Witcombe, J.R.; Joshi, A. and Sthapit, B.R. (1996) 'Farmer Participatory Crop Improvement 1. Varietal Selection and Breeding Methods and Their Impact on Biodiversity', Experimental Agriculture 32: 445-60

Witcombe, J.R.; Joshi, K.D.; Gyawali, S.; Musa, A.M.; Johansen, C.; Virk, D.S. and Sthapit, B.R. (2005) 'Participatory Plant Breeding is Better Described as Highly Client-oriented Plant Breeding. 1. Four Indicators of Clientorientation in Plant Breeding', Experimental Agriculture 41: 299-319

World Bank (1999) Consultations with the Poor: Process Guide for the 20 Country Study for the World Development Report 2000/01, Poverty Group, Poverty Reduction and Economic Management Network, Washington DC: World Bank 